\title{
Cryopreservation of Mouse Spermatozoa
}

\author{
Tsutomu TAKESHIMA, Naomi NAKAGATA*, \\ and Shyoso OGAWA**
}

\begin{abstract}
Imamichi Institute for Animal Reproduction, 1103 Fukaya, Dejima-mura, Niihari-gun, Ibaraki 300-01, * Central Laboratory of Medical Sciences, Divison of Pathology, Juntendo University School of Medicine, 2-1-1 Hongo, Bunkyo-ku, Tokyo 113, and ${ }^{* *}$ Laboratory of Animal Reproduction, Faculty of Agriculture, Meiji University, 1-1-1 Higashimita, Tama-ku, Kawasaki-shi, Kanagawa 214, Japan
\end{abstract}

(Received 6 March 1991/Accepted 11 June 1991)

\begin{abstract}
The spermatozoa of cauda epididymis of mature mice were suspended in $3 \%$ skim milk in distilled water supplemented with $12,15,18$ or $21 \%(\mathrm{~W} / \mathrm{V})$ raffinose. The suspension of spermatozoa were frozen in liquid nitrogen gas for $10 \mathrm{~min}$, then stored in liquid nitrogen $\left(-196^{\circ} \mathrm{C}\right)$. The frozen suspensions of spermatoza were thawed by rapid warming in water bath at room temperature. For removing the cryopreservative solution, a pair of syringes connected with a three stop cock and a filter unit (pore size $0.45 \mu$ ) were used. Highest sperm motility was obtained after $1 \mathrm{hr}$ of thawing from the cryopreservative solution containing $18 \%$ raffinose and $3 \%$ skim milk. These cryopreserved spermatozoa were used for fertilization in vitro. The proportion of pronuclear oocytes was $35.9 \%(74 / 206) 6 \mathrm{hr}$ after insemination, and the proportion of 2-cell embryos was $33.6 \%$ (42/125) $28 \mathrm{hr}$ after insemination. All 2-cell embryos were transferred to the oviducts of pseudopregnant recipients and 45. 2\% (19/42) developed to normal young. - KEY WORDS : cryopreservation, in vitro fertilization, mouse spermatozoa, raffinose, skim milk
\end{abstract}

\section{マウス精子の凍結保存}

竹島 勉 $\cdot$ 中潟直已* · 尾川昭三**

\author{
財団法人動物繁殖研究所 \\ *順天堂大学医学部共同研究室 \\ ***明治大学農学部家畜育種繁殖学研究室
}

小実験動物としてのマウスは，畜産，遗伝，免度およ び医学等の分野で基礎的な実験に多く用いられ，現在， その系統 (近交系,ミュータント系, トランスジェニッ ク系等）は膨大な数になっている。これらの系統を維持 管理することは労力および施設面で大きな負担を生じる ため, 配偶子や胚の凍結による系統保存が必要になる。 マウス胚の凍結保存は whittingham 5 [7] が成功し て以来, 多くの研究がなされ実用化されている。一方, マウス精子の凍結保存は著者らが第17回日本実験動物学
会で Raffinose を主成分とした凍害保護物質で成功し て以来, 奥山ら [2], 多田ら [4], 横山ら [8] により 種々の改良を加えた報告がされているにすぎない。本報 告では，マウス精子の凍結保存法を簡易化し，系統維持 への実用化を目的として, 保存液の作製, 凍結一融解お よび保存液の除去法について検討した。 


\section{材料および方法}

凍結保存液 : Reffinose (和光純薬) 12，15，18 およ び21\%にそれぞれ Skim Milk (Difco) 3\%となるよう に蒸留水に加え， $60^{\circ} \mathrm{C}$ の水温中で溶解した。これを超䞦 心機 $(10,000 \mathrm{~g})$ で15分間遠心分離してカゼインミセル を除去し，その上清を $0.45 \mu$ のディスポーザブル・フィ ルターュニット (Millipore, SLHA 025 OS) を用いて濾 過隇菌した。濾過隇菌した保存液を小試験管に分注し て， $-80^{\circ}$ Cで保存し，実験前に室温に戻して使用した。

精子採取：ICCR 采マウス（10１5週龄）雄の精巣上 体尾部 4 個を Organ tissue culture dish (Falcon 3037）内の $0.4 \mathrm{ml}$ の保存液に入れ, 眼科用八サミで細 切した後, Organ tissue culture dish を約 1 分間, 円 を描くように回転し, 精子を精巣上体管から保存液に拡 散させて採取した。保存液内に均一に拡散した精子浮遊 液を $0.5 \mathrm{ml}$ のサンプリングチューブ (Sarstedt, 72.699 $\mathrm{S}$, Nümbrecht, Germany) に約 $0.1 \mathrm{ml}$ ずつ分注し, 凍結保存に供した。

凍結操作 : 精子液の入ったサンプリングチューブを密 栓してホルダー（Fig. 1) に固定し, $50 \mathrm{ml}$ のディスポ ーザブル注射筒の先端に発泡スチロールを詰め作製した
凍結用キャニスター（Fig.1）に入れ, 液体窒素液面 に浮かし，10分間静置した。その後，凍結用キャニスタ 一を夜体窒素中に沈め，10分後，ホルダーに固定したま まサンプリングチューブを保存用キャニスターに移し， $1 \sim 7$ 日間, 液体窒素中で保存した（室温よりー196 C まで 30 $40^{\circ} \mathrm{C} / \mathrm{min}$ の速度で泠却)。

融解怙よび融解後の保存液の希釈・除去 : 液体窒素保 管器からサンプリングチューブを取り出し, 室温水槽に 静置して融解した（3～5 分, $50 \sim 80^{\circ} \mathrm{C} / \mathrm{min}$ の速度で 融解)。サンプリングチューブ内の精子夜が完全に融解 したことを確認した後, $2 \mathrm{ml}$ の HTF 液 [3] を予め吸 引しておいた $2.5 \mathrm{ml}$ ディスポーザブル注射筒（テルモ） に精子夜をすべて吸引した。注射筒の先端に $0.45 \mu$ のデ 1スポーザブル・フィルターュニットと三方活栓 (TOP, $9 \mathrm{H} 03 \mathrm{Y}$ ) および三方活栓中央の接続部に $5 \mathrm{ml}$ の HTF 液を吸引した $5 \mathrm{ml}$ のディスポーザブル注射筒（テルモ） を装置し (Fig. 2), 以下の操作を行なった。三方活 栓のコックCを止め, $2.5 \mathrm{ml}$ の注射筒を完全に押し出 した後 (液の流れ $\mathrm{A} \rightarrow \mathrm{B}$ ), 三方活栓のコック $\mathrm{B}$ を止め, $5 \mathrm{ml}$ の注射筒より $2.5 \mathrm{ml}$ の注射筒内へ, $2 \mathrm{ml}$ の HTF 液を静かに注入した（液の流れ $\mathrm{C} \rightarrow \mathrm{A}$ )。この操作を 2 回行なった後, $0.6 \mathrm{ml}$ の HTF 液を $2.5 \mathrm{ml}$ の注射筒に 吸引し(液の流れ $\mathrm{C} \rightarrow \mathrm{A})$ ) ディスポーザブル・フィルタ

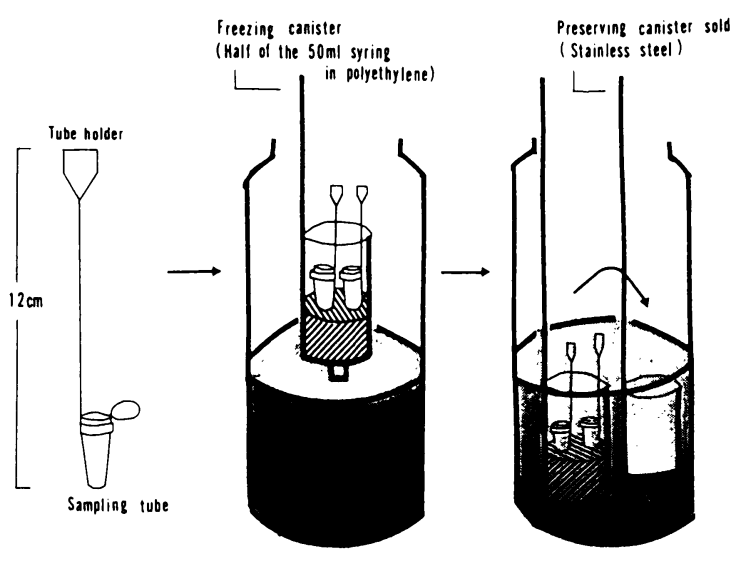

Fig. 1. Freezing of mouse spermatoza

(1) The sperm suspension $(0.1 \mathrm{ml})$ was transferred into a sampling tube. (2) The freezing canister was kept $10 \mathrm{~min}$ in $\mathrm{LN}_{2}$ gas. (3) The freezing canister was plunged directly into $\mathrm{LN}_{2}$. Then, the sampling tube with the holder was moved from the freezing canister to the preserving canister.

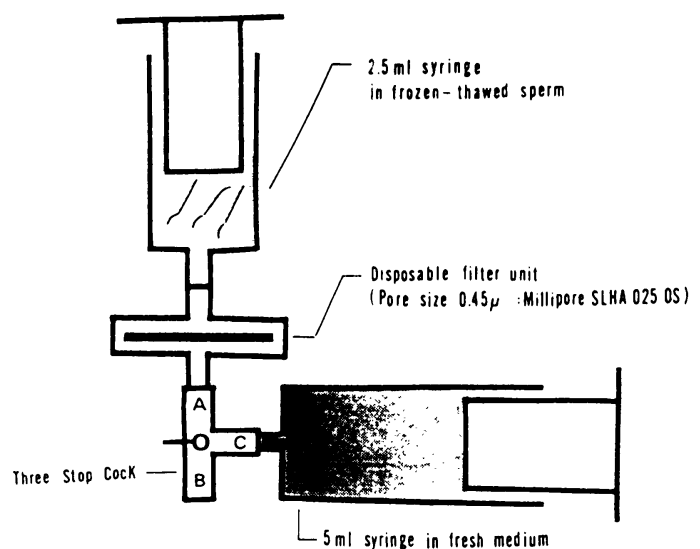

Fig. 2. Dilution of sperm suspension after thawing (1) The sperm suspension was filtered by pushing the upper syringe after closing $\mathrm{C}$ cock (A flowing to B). (2) $2 \mathrm{ml}$ of fresh HTF medium was withdrawn into the upper syringe by pushing the lower syringe after closing $\mathrm{B}$ cock ( $\mathrm{C}$ flowing to $\mathrm{A}$ ). (3) This procedure was repeated once more. 
ーニニットを $2.5 \mathrm{ml}$ の注射筒から取り外した。得られ た精子液を $0.2 \mathrm{ml}$ ずつパラフィンオイル下の $0.2 \mathrm{ml} の$ HTF 液に注入し，体外受精用精子懸濁液を作製した (3,000 4, 000 精子/ $\mu 1)$ 。これを 1 時間, 炭酸ガス培盖 装置 $\left(37^{\circ} \mathrm{C}, 5 \% \mathrm{CO}_{2}, 95 \%\right.$ 空気) 内でインキュベート した後, 精子の運動性を $37{ }^{\circ} \mathrm{C}$ 加温したスライドグラス 上にて鏡検した。

体外受精 : 体外受精は豊田ら [7,8] の方法に従った。 すなわち, 5 IU PMSG と 5 IU hCG を48時間間隔で腹 腔内投与した ICR 系雌マウス（ $8 \sim 12$ 週龄）の卵管膨 大部より hCG 注射後，16〜17 時間に卵子を採取した。 この卵子を 1.5 時間前培養した精子熙濁液内に導入し, 体外受精を行なった。卵子の観察は授精後 6 時間にホー ルマウント標本を作製して行ない, 一部の卵子について

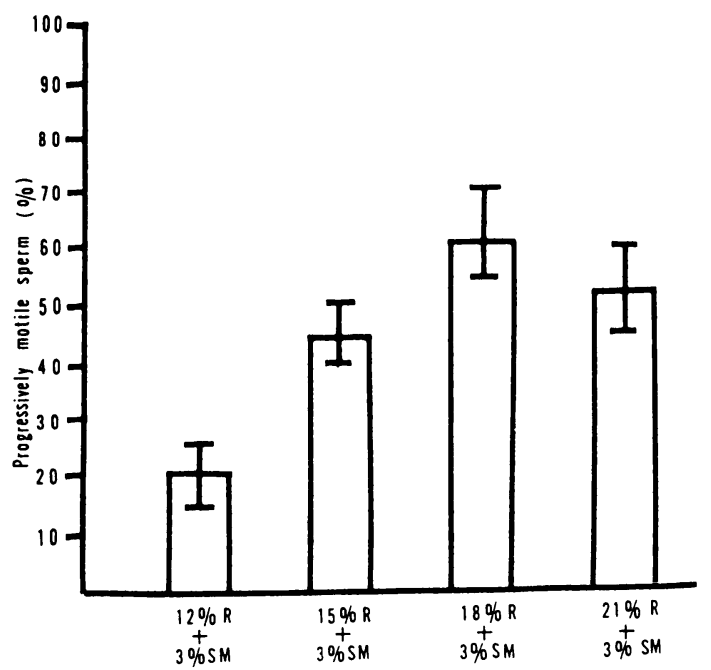

Fig. 3. The motility of frozen-thawed mouse spermatozoa R: Raffinose SM: Skim Milk
はさらに22時間の培養を続け， 2 細胞期への発生につい て観察した。

泼の移植 : 授精28時間後に 2 細胞期へ発生した胚を精 管結禁雄と交配した C 57 BL/6 N 倠の卵管内に偽妊娠 第一日目に移植し，新生仔への発生について検討した。

\section{成程}

Fig. 3 に 12，15，18 拈よび 21\% Raffinose に $3 \%$ Skim Milkを加えた保存液で凍結一融解後, 1 時間培 養した精子の運動性を示す。すべての実験群で精子の䄪 半数に運動性が認められ, 精子活力の評価は運動性を呈 している精子に対する前進運動精子数の割合として算出 した。その結果, 18\% Reffinose+ $3 \%$ Skim Milkの 実験群では, 前進運動精子の割合が約60\%であり, 他の 実験群を上回っていた。Table 1 に, この精子を用いて 体外受精した受精成績を示す。凍結精子を用いて体外受 精した卵子の受精率は 35.9\%（74/206）であり, 対照群 の 92.9\%（104/112）と比べて低値を示していたが，多 精子侵入卵は認めれなかった。

Table 2 に, 18\% Reffinose+ 3 \% Skim Milk で凍 結した精子を用いて体外受精した卵子の 2 細胞期への 発生率を示す。 2 細胞期胚への発生率は, 凍結精子で $33.6 \%$ (42/125), 対照群で $90.4 \%$ (47/52) であった。 Table 3 に, この 2 細胞期胚を偽妊娠倠に移植した成樍 を示す。凍結群で 2 細胞期に発生した42個の泼を 4 匹の 偽妊娠倠に移植した結果, 3 匹が妊娠し19匹 (45.2\%) の新生仔が得られた。対照群では，46個の泼を 3 匹に移 植し, 全例が妊娠し, 23匹 (50.0\%) の新生仔が得られ た。

家畜では, ウシ精子の凍結保存に $18 \%$ Raffinose を

Table 1. The fertilization rate in vitro by frozen-thawed mouse spermatozoa $6 \mathrm{hr}$ after insemination

\begin{tabular}{lcrcc}
\hline \multirow{2}{*}{ Sperm } & \multirow{2}{*}{$\begin{array}{l}\text { No. of } \\
\text { oocytes } \\
\text { examined }\end{array}$} & \multicolumn{3}{c}{ No. of oocytes fertilized* } \\
\cline { 3 - 5 } & Total $(\%)$ & Monospermic & Polyspermic \\
\hline Fresh (Control) & 112 & $104(92.9)$ & 97 & 7 \\
Frozen-thawed & 206 & $74(35.9)$ & 74 & 0 \\
\hline
\end{tabular}

* Oocytes at Telophase II with enlarged sperm head (s) in vitellus, or oocytes with male and female pronuclei 
Table 2. Development of 2-cell embryos from the oocytes fertilized by frozen-thawed mouse spermatozoa $24 \mathrm{hr}$ after insemination

\begin{tabular}{ccc}
\hline Sperm & $\begin{array}{l}\text { No. of } \\
\text { oocytes } \\
\text { examined }\end{array}$ & $\begin{array}{l}\text { No. of oocytes } \\
\text { developed to } \\
\text { 2-cell embryos }(\%)\end{array}$ \\
\hline Fresh (Control) & 52 & $47(90.4)$ \\
Frozen-thawed & 125 & $42(33.6)$ \\
\hline
\end{tabular}

Table 3. Development to live young of 2-cell embryos from the oocytes fertilized by frozen-thawed mouse spermatoza after transfer to pseudopregnant recipients

\begin{tabular}{|c|c|c|c|c|c|c|}
\hline \multirow{2}{*}{ Sperm } & \multirow{2}{*}{$\begin{array}{l}\text { No. of } \\
\text { recipients } \\
\text { used }\end{array}$} & \multirow{2}{*}{$\begin{array}{l}\text { No. of } \\
\text { embryos } \\
\text { transferred }\end{array}$} & \multirow{2}{*}{$\begin{array}{l}\text { No. of animals } \\
\text { which delivered } \\
\text { live young }\end{array}$} & \multicolumn{3}{|c|}{ No. of live young } \\
\hline & & & & 우 & $0^{7}$ & Total $(\%)$ \\
\hline & 3 & 46 & 3 & 14 & 9 & $0.0)$ \\
\hline Frozen-thawed & 4 & 42 & 3 & 8 & 11 & $19(45.2)$ \\
\hline
\end{tabular}

用い，良好な成績が認められている $[1]$ 。しかし，マウ ス精子では, Raffinoseのみでは耐凍効果は不十分であ り,これにSkim Milk, Glycerol あるいはDMSOを 添加することで耐凍効果が向上することが報告されてい る $[2,4,8]$ 。本実験では, $3 \%$ Skim Milk を含む 12 , 15，18 および 21\% Raffinose 浱度で涷結した精子の融 解後の運動性は, 18\% Raffinose が最も良好であり, その精子の体外受精における受精率は, 授精後 6 時間で $35.9 \% ， 2$ 細胞期での検查で33.6\%であった。この成績 は, 対照群に比較して低値であったが, マウス精子の凍 結保存に有効であることを示している。従って, 第17回 日本実験動物学会で著者らが Raffinose を主成分とした 保存液を用い, マウス精子の凍結保存を報告した成績と ほぼ同様な結果であった。しかし, 本実験では, 次の点 に改良を加えてある。すなわち，1）試薬用 Skim Milk を用い, Raffinose とともに蒸留水に溶解後, 超遠心分 離で巨大分子のカゼインミセルを除去した上清を保存液 とすることで，均一化した保存液を作製した。2）凍結 操作では, 液体窒素保管器内で液体窒素ガスに10分間静 㯰後, 液体空素に浸漬するといら簡易で短時間の二段階 急速凍結法を用いた。3）融解後, ディスポーザブル . フィルターュニットおよび三方活栓を用い, 無菌的に, かつ短時間で涷害保護物質を除去した。これらの工夫に より, 凍結から融解後の精子操作を簡易化し, 精子に与 える悪影響を軽減できたと考える。従って, 今後, 凍
結一融解精子の受精率を向上させることにより, 精子の 凍結保存の実用性がより高まるものと考える。

\section{要 約}

12，15，18，21\%の Raffinose (W/V) に $3 \%$ Skim Milk を加えた保存液を用いマウスの精巣上体尾部精子 を凍結保存した。凍結は試料を室温から液体窒素ガス中 に10分間静置後, 液体窒素内に浸漬する急速冷却法を 用いた。融解は, 試料を液体窒素から取り出し, 室温水 槽に静置することにより行なった。融解した精子浮遊夜 を注射筒内に吸引後, 注射筒先端に $0.45 \mu$ のディスポー ザブル・フィルターュニットと三方活栓を装置し, 濾 過することにより保存液を除去した。その結果，18\% Raffinose に $3 \%$ Skim Milkを添加した保存液で涷結 保存した精子が，融解後 1 時間の運動性で最も優れてい た。この精子を用いて体外受精を行ない，授精 6 時間後 の受精率および28時間後の 2 細胞期への発生率は, そ れぞれ35.9\% (74/206) および33.6\% (42/125) であっ た。また， 2 細胞期肧を受容雌の卵管内に移植し， 45.2 \%（19/42）が新生仔として得られた。

本研究の一部は文部省科学研究費補助金 (No. 57771578, 58771720)によるものである。本研究に御協力いたたいた明治 乳業株式会社, 中央研究所, 米久保明氏に対し感謝致します。 


\section{文 献}

［1］永瀬 弘（1975）. 牛精子に対する凍害防止剂の種類と その効果一錠剤法を利用する凍害防止剂の検索一. 農林 省畜産試検場年報, $15,109-132$.

［2］奥山 学・磯貝滋樹・佐賀正彦・浜田 宏・尾川昭三 （1990）。、マス凍結精子の体外受精および人工授精試 験. 日本受精着床学会誌, 7,116-119.

[3] Quinn, P., Kerin, J. F., and Warnes, G. M. (1985). Improved pregnancy rate in human in vitro fertilization with the use of a medium based on the composition of human tubal fluid. Fertility and Sterility, 44, 493-498.

[4] Tada, N., Sato, M., Yamanoi, J., Mizorogi, T., Kasai, K., and Ogawa S. (1990). Cryopreservation of mouse spermatozoa in the presence of raffinose and glycerol. J. Reprod Fert. 89, 511-516.

［5］豊田 裕・横山峷介・星冬四郎 (1971)，、ウス卯子の体 外受製に関する研究 I. 精巣上体精子による受精成瞔。 家畜繁殖誌, 16, 147-151

［6]豊田 裕・横山峷介・星冬四郎 (1971)。 マウス卵子の 体外受精に関する研究 II . 精子侵入時期に及ぼす精子体 外培養の効果. 家畜繁殖誌, 16, 152-157.

[7] Whittingham, D. G., Leibo, S P., and Mazur, P. (1972). Survival of mouse embryos frozen to -196 ${ }^{\circ} \mathrm{C}$ and $-269^{\circ} \mathrm{C}$. Science, 187, 411-414.

［8］横山峷介・秋葉久弥・勝木元也・野村達次 (1990). 凍 結保存マウス精子の体外受精による正常産仔の作成. 実 験動物. 39, 125-128. 